\title{
磁性材料・磁気デバイスにおけるナノ・マイクロ構造制御 Control and Manipulation of Nano- and Micro-structure in Magnetic Materials and Devices
}

\author{
北本 仁孝 \\ Yoshitaka KITAMOTO \\ 東京工業大学 \\ Tokyo Institute of Technology
}

硬磁性，軟磁性のいずれにおいても，ナノメートルからマ イクロメートルのスケールで結晶構造・形態的構造を制御す ることが磁性材料の磁気物性の操作, それらを用いた磁気デ バイスの機能発現にとって重要な課題となっています。そこ で, 磁性材料・磁気デバイスにおけるナノ・マイクロスケー ルでの微細構造創製技術，および評価技術に関する話題を広 く募集し，新しい展開ができるような討論を実施したいと考 え, 本講演特集を企画しました。

2 件の特別講演を含む, 33 件の講演で7つのセッションを 実施しました。約 100 名を収容できる会場でしたが，聴講者 が会場に入りきらないような場面もあり，全体を通して大盛 況でした．特定のテーマに偏ることなく，幅広い分野から講 演が行われ，磁気関連の材料技術のすそ野が広いことを感じ させるものでした. 講演者, 参加者も企業, 大学など多様で, この分野が産と学から広く関心を持たれていると同時に，連 携により進展していることを多くの方が感じたことと思いま す. 以下に各セッションの様子を紹介します.

初日の第 1 セッションは, 硬磁性を示すフェライトに関す る発表があり, $\mathrm{M}$ 型, $\mathrm{W}$ 型の六方晶フェライトに加え, Co 系スピネルフェライトの研究成果が報告されました．希土類 系以外の硬磁性材料も重要であることを認識することのでき る発表であったと言えます.

第 2 セッションから第 4 セッションにかけて, 合金系硬磁 性材料の講演が続きました。 ナノコンポジット磁石の視点か らの $\mathrm{Fe}$ と $\mathrm{Mn}-\mathrm{Bi}$ との複合化事例に続き, Sm-Fe系材料にお いて作製プロセスを変えることにより，組織の微細化，準安 定相の創造をはかる研究成果が発表されました。元素の添加 による結晶成長抑制など微細化がキーワードとなる講演が続 きました。

第 3 セッションで行われた特別講演では, 液相合成により
規則合金 FePd と Fe とをコアシェル型に複合化したナノコン ポジット磁石材料について発表されたのち， $\mathrm{Ga}$ 添加による 重希土類元素の添加に強く依存しない Nd-Fe-B 系合金の高保 磁力化が報告されました。 このあと Nd-Fe-B 系磁石の講演が 続き, 微細構造, 粒界構造制御による高磁気エネルギー化を 目指す研究発表がなされました。

さらに硬磁性材料として, Fe-Pt 合金薄膜, ナノ粒子アレ イに関して磁気記録媒体の視点から，規則合金化のための熱 処理と微細構造制御との相関が発表されました。

第 5 セッションは磁性ナノ粒子における新規手法による合 成と磁性材料の新しい応用であるバイオ医療分野に関する講 演, さらにはフェライト以外の化合物磁性体の講演とで構成 されました。ここでもナノ粒子の合成と応用が注目され，微 細構造制御がキーワードとなっていました.

第 2 日の第 6 セッションは圧粉磁心など軟磁性材料の講演 で構成されました。このセッションは企業からの講演がその 他と比較して多く，また粉末のような素材だけでなくモー夕 のようなデバイスの発表もありました. このセッションの参 加者が最も多く，エネルギーをテーマとしたものが引き続き 社会の興味を引き付けるものであることを実感しました.

最終の第 7 セッションでは, 高周波応用を目指したフェラ イトや新規形状を有するフェライト材料に関する講演がなさ れました，第 1 セッションのフェライトとは異なった応用， 視点の発表でしたが, 両セッションの発表から本協会におい てフェライトの存在意義が大きいことをあらためて認識する ことができたと感じました.

このように大盛況のセッションを実施できましたのは，発 表者, 参加者の皆様のおかげと感謝申し上げたいと思いま す．また，今後も広くこの分野を俯瞰することのできる講演 特集を企画していきたいと思います。 